\title{
Faktor-Faktor Kinerja terhadap Indeks Produksi Ayam Broiler di Experimental Farm, Fakultas Peternakan, Universitas Jenderal Soedirman
}

\author{
Sufiriyanto $^{1 *}$, Adi Fathul Qohar ${ }^{1,2}$, Nur Hidayat ${ }^{1}$, Muhamad Samsi $^{1}$ \\ ${ }^{1}$ Fakultas Peternakan, Universitas Jenderal Soedirman \\ ${ }^{2}$ Mahasiswa Magister Peternakan, Fakultas Peternakan, Universitas Jenderal Soedirman \\ *Corresponding author: sufiriyanto@unsoed.ac.id
}

\begin{abstract}
Abstrak
Penelitian ini bertujuan untuk mengkaji faktor-faktor yang berpengaruh terhadap indeks produksi ayam broiler di experimental farm, milik Fakultas Peternakan. Metode penelitian yakni studi kasus, dengan analisis yang digunakan adalah regresi linier berganda. Parameter yan diteliti adalah rasio konversi pakan, daya hidup, penambahan bobot badan harian, dan indeks produksi. Hasil penelitian menunjukan bahwa faktor-faktor kinerja berpengaruh signifikan $(\mathrm{P}<0.05)$ terhadap indeks produksi ayam pedaging di experimental farm. Uji F secara simultan yakni faktor-faktor kinerja berpengaruh sebesar 98,7 persen terhadap indeks produksi ayam broiler. uji t secara parsial yakni pertambahan bobot badan harian sebesar 20,2 persen, daya hidup sebesar 30,1 persen, dan konversi pakan sebesar 48,4 persen terhadap indeks produksi ayam broiler. Konversi pakan merupakan faktor yang paling dominan berpengaruh terhadap indeks produksi, diikuti oleh daya hidup, dan pertambahan bobot badan harian.
\end{abstract}

Kata kunci: Ayam broiler, Faktor-faktor kinerja, Indeks produksi

\begin{abstract}
This study examines the factors that influence the production index of broiler chickens in the experimental farm owned by the Faculty of Animal Science. The research method is the case study, with the analysis used is multiple linear regression. The parameters studied were the feed conversion ratio, viability, daily body weight gain, and production index. The results showed that the performance factors had a significant effect $(\mathrm{P}<0.05)$ on the experimental farm's broiler production index. Simultaneous F-test, namely the performance factors, affect 98.7 percent of the broiler production index. Partial t-test, namely daily body weight gain of 20.2 percent, the vitality of 30.1 percent, and feed conversion of 48.4 percent to the broiler production index. Feed conversion is the most dominant factor affecting the production index, followed by the vitality and daily body weight gain.
\end{abstract}

Keywords: Broiler chickens, Performance factors, Production index 
Prosiding Seminar Nasional Pembangunan dan Pendidikan Vokasi Pertanian

Politeknik Pembangunan Pertanian Manokwari, 14 November 2020

e ISSN : 2774-1982

\section{PENDAHULUAN}

Pemeliharaan ayam broiler di Eksperimental Farm Fakultas Peternakan sejak awal pada bulan Juli tahun 2018 sudah menggunakan kandang tertutup atau Closed House $(\mathrm{CH})$ berukuran 7x20 m untuk kapasitas 1900 ekor dan tiga kandang terbuka atau Open House $(\mathrm{OH})$ yaitu kandang $\mathrm{OH}$ selatan ukuran 6x 15m untuk kapasitas 700 ekor, kandang $\mathrm{OH}$ timur ukuran 6 m x15 m untuk kapasitas 900 ekor dan kandang $\mathrm{OH}$ utara dengan ukuran 6 x21 m untuk kapasitas 1200 ekor. Produktivitas dipengaruhi oleh banyak factor dan diantara nya adalah ada tiga factor, yaitu faktor bibit, faktor pakan dan faktor manajemen. Pemeliharaan di exfarm produktivitasnya hanya ditentukan manajemen saja karena factor bibit dan factor pakan dikendalikan perusahaan dalam hal ini pihak inti, Evaluasi kinerja produktivitas ayam broiler kandang $\mathrm{CH}$ dan kandang $\mathrm{OH}$ dilaksanakan per periode atau system all in - all out, pakan menggunakan starter untuk umur 1-20 hari dan finisher umur 20 sampai panen umur 30 - 37 hari.Kelebihan kandang $\mathrm{CH}$ yaitu dapat mengatur temperature dalam kandang, membuang gas beracun seperti $\mathrm{CO}, \mathrm{CO} 2$ dan $\mathrm{NH} 3$ (amonia) dengan mengatur Oksigen atau udara masuk in let dari cooling pad dan mengatur udara keluar out let melalui blower atau exhouser (Prihandanu, dkk, 2011). Kecepatan angin di dalam kandang $\mathrm{CH}$ sebesar $450 \mathrm{f} / \mathrm{m}$ atau 2,25 m/s (Dahlan, dkk, 2011) sedangkan Dika, dkk (2018) mengatakan bahwa kecepatan angin dalam kandang rata-rata sebesar 2,98 m/s, hal ini menunjukkan adanya perbedaan kecepatan angin dalam kandang pada masa awal dan masa produksi. Pengaturan blower digabungkan atau setting dengan tempron (pengatur temperature), kerja blower dapat direct (langsung), intermitten (selang seling) dan indirect (tidak langsung), selanjutnya Bulan (2018) mengatakan kandang $\mathrm{CH}$ dengan pengatur suhu berdasarkan pengaturan putaran blower.

\section{METODE}

Penelitian dilaksanakan dengan metode studi kasus setiap periode pemeliharaan dilaksanakan evalusi .Pada pemeliharaan ayam niaga pedaging periode broding menggunakan $\mathrm{CH}$ sejumlah 3000 ekor sampai 4000 ekor, setelah 12 hari ayam dibagi ke kandang tertutup CH ukuran sebanyak 1800-1900 ekor, kandang terbuka $\mathrm{OH}$ selatan kapasitas 600-700 ekor, kandang terbuka $\mathrm{OH}$ tmur kapasitas 700-900 ekor dan kandang terbuka $\mathrm{OH}$ sebelah utara kapasitas 1000-1200 ekor Dilaksanakan pengamatan dan recording kandang serta gejala 2 sakit atau pengamatan dan tindakan apabila ada gangguan pada ayam broiler .Kinerja brroiler meliputi : Indeks produksi (IP), Feed Conversi Rasio (FCR), Mortalitas, Bobot badan mingguan, bobot badan panen dan umur panen. Evaluasi 
Prosiding Seminar Nasional Pembangunan dan Pendidikan Vokasi Pertanian

Politeknik Pembangunan Pertanian Manokwari, 14 November 2020

e ISSN : 2774-1982

studi kasus kinerja ayam broiler kandang $\mathrm{CH}$ dan kandang $\mathrm{OH}$ dengan analisis uji Regresi linear berganda , apabila signifikan berbeda dilanjutkan uji F simultan partial

\section{HASIL DAN PEMBAHASAN}

Indek Produksi merupakan perkalian daya hidup dengan rattan bobot badan harian, dibagi FCR dikalikan sepuluh.Hal ini sesuai dengan Lyons (1993) yang mengatakan bahwa indek produksi dapat digunakan sebagai pedoman penentuan produktivitas broiler., dikelompokkan menjadi empat nilai >400 sangat baik, nilai 350-400 dikatakan baik, nilai 300-350 dikatakan cukup baik dan nilai <300 dikatakan kurang baik. Daya hidup atau livebility merupakan persentasi jumlah ayam hidup dikurangi persentasi jumlah ayam mati. Sedangkan angka deplesi merupakan jumlah ayam mati ditambah ayam afkir yang tidak dapat dijual..Untuk FCR atau konversi pakan merupakan perbandingan antara pakan yang dihabiskan dibagi dengan bobot badan yang dihasilkan atau dengan kata lain jumlah pakan yang dimakan untuk membuat bobot badan seberat satu kilogram.

Tabel 1. Rataan Faktor-Faktor Kinerja dan Indek Produksi

\begin{tabular}{cccc}
\hline PBBH & DH & FCR & IP \\
\hline 65,43 & 96,28 & 1,36 & 466,00 \\
65,25 & 91,34 & 1,52 & 393,40 \\
62,12 & 93,50 & 1,48 & 401,10 \\
66,82 & 96,50 & 1,51 & 390,50 \\
55,37 & 91,15 & 1,58 & 320,40 \\
58,82 & 95,38 & 1,50 & 374,80 \\
54,11 & 93,53 & 1,68 & 300,40 \\
54,62 & 94,22 & 1,64 & 314,60 \\
54,00 & 96,55 & 1,65 & 314,30 \\
58,76 & 96,17 & 1,56 & 361,50 \\
52,91 & 71,49 & 1,64 & 230,30 \\
49,56 & 72,00 & 1,68 & 217,73 \\
\hline
\end{tabular}

Pemeliharaan periode Oktober-November 2018 menunjukkan kinerja broiler sangat baik, dengan nilai indek produksi 466 untuk kandang $\mathrm{CH}$ dan kandang $\mathrm{OH}$ dengan rataan nilai 391,69.(lihat table 1) Hal ini menunjukkan bahwa kandang $\mathrm{CH}$ lebih baik disbanding $\mathrm{OH}$, dikarenakan suhu atau temperatur dalam kandang dapat diatur sesuai dengan standart temperature kebutuhan ayam. Hal ini sesuai dengan Charles (1993) yang mengatakan bahwa performan menjadi baik diberikan temperatut $20-22^{\circ} \mathrm{C}$, pada pemeliharaan starter umur 1-2 hari diberikan temperature $30-35^{\circ} \mathrm{C}$ dan semakin tambah umur terperatur dalam kandang diturunkan bertahap. Sedangkan Pratama, dkk (2015) 
Prosiding Seminar Nasional Pembangunan dan Pendidikan Vokasi Pertanian Politeknik Pembangunan Pertanian Manokwari, 14 November 2020

e ISSN : 2774-1982

mengatakan bahwa terperatur periode starter $33-35^{\circ} \mathrm{C}$ dengan kelmbaban $60-80 \%$ setelah 14 hari dibuat temperature sebesar $28-29^{\circ} \mathrm{C}$ Pada waktu pemeliharaan periode ini, menggunakan pengaturan temperature pada starter umur $1-2$ hari $33^{\circ} \mathrm{C}$; umur 3 hari $32^{\circ} \mathrm{C}$; umur 4-5 hari sebesar $31^{\circ} \mathrm{C}$; umur 6-8 hari sebesar $30^{\circ} \mathrm{C}$; umur 9-12 hari sebesar $29{ }^{\circ} \mathrm{C}$; umur 13-17 hari sebesar $28^{\circ} \mathrm{C}$ dan selanjutnya temperature sebesar $27^{\circ} \mathrm{C}$.Periode starter (brooding) ini pemanas (heater) sangat menentukan pertumbuhan ,konsumsi pakan, efisiensi pakan, kesehatan anak ayam dan mortalitas.. Temperatur masa brooding atau masa starter sangat menentukan performan ayam broiler (Wijayanti dkk, 2013).

Pemeliharaan ayam niaga pedaging periode Mei- Juni 2019 menunjukkan hasil kinerja broiler cukup baik saja, dengan nilai IP sebesar 320,40 untuk kandang $\mathrm{CH}$ dan kandang $\mathrm{OH}$ dengan nilai rataan 327,89 . Hal ini disebabkan banyak factor dan diantaranya faktor DOC dengan BB 36 gram dan factor kematian (mortalitas) serta diketemukan factor deplesi tinggi untuk $\mathrm{CH}$ dikarenakan adanya hama tikus dan kucing, serangan kucing lewat bawah cooling ped, menangkap anak ayam dibunuh dan ditinggalkan, menangkap anak ayam yang lain, sulit diperkirakan anak ayam yang diterkam atau dibunuh. Pencegahan dengan jaga malam kurang efektif karena menyerang menjelang pagi sekitar jam 02.00 sampai dengan pukul 04.00 WIB Faktor lain adalah faktor bobot DOC yang rendah yaitu dibawah 36 gram , diduga kemungkinan adanya peremajaan di breeding farm sehingga DOC yang dihasilkan masih kecil-kecil .Bibit anak ayam niaga pedaging yang kecil akan memberikan produktivitas tidak optimal (Fadillah dan Fatkhuroji, 2013). Ditinjau dari pakan kelihatannya tidak berpengaruh karena pakan starter dengan kandungan protein kasar $22 \%$ dan pakan finisher protein kasar 20\% sudah baik, tetapi apabila dilakukan pemberian pakan berbeda-beda perusahaannya maka akan memberikan hasil signifikan berbeda $(\mathrm{P}<0,05)$ di bobot badan akhir.sedangkan untuk karkas tidak signifikan berbeda (Sufiriyanto, dkk. 2018). Faktor penyebab turunnya produktivitas tehnik adalah putaran exhouser (pembuang udara) tidak maksimal dikarenakan karet atau belt mulai longgar, sehingga pergantian udara tidak optimal, ditambah lagi adanya gangguan pinggir kandang yang sudah mulai berlubang keropos. Hal ini sesuai dengan Prihandanu (2015) yang mengatakan bahwa pemeliharaan kandang tertutup diperlukan pengaturan ventilasi yang baik untuk pengadaan oksigen dan untuk membuang ammonia dari dalam kandang. Karena ammonia di dalam kandang sangat berpengaruh nyata terhadap kesehatan ayam, performan dan hasil panen (karkas). 
Prosiding Seminar Nasional Pembangunan dan Pendidikan Vokasi Pertanian Politeknik Pembangunan Pertanian Manokwari, 14 November 2020

e ISSN : 2774-1982

Pemeliharaan pada periode November-Desember 2018 memberikan kinerja broiler tidak baik atau jelek karena adanya pengaruh faktor bibit DOC sebesar 30\% Pada waktu musim penghujan terjadi hujan terus menerus selama tujuh hari, kalau orang jawa bilang jatuh hujan renteng, kebetulan ayam baru dipindah dari kandang $\mathrm{CH}$ ke kandang terbuka $(\mathrm{OH})$, hujan lebat disertai angin kencang sehingga banyak tampias hujan yang mmasuk ke kandang terbuka. Tirai mulai diup sepertiga kandang sebagian pada waktu hujan siang dan malam dituttup sebagian, tetapi kondisi ayam mulai menunjukkan gejala sakit muka agak bengkak, kotoran sedikit putih kehijauan dan mulai batuk ringan. Pemeriksaan dari pihak inti member saran untuk diberikan vitamin, sebenarnya kami mitra kurang setuju, kondisi ayam kandang selatan parah banyak kematian di lanjutkan kandang timur.

Hasil bedah bangkai menunjukkan adanya enteritis sehingga dilanjutkan pengobatan dengan Gentamisin. Hasil pemeriksaan bedah bangkai menunjukkan penyakit ND dan dilakukan ambil darah untuk uji HI (Hemaglutinasi Inhibition), hasil menunjukkan terserang sakit ND dengan titir ND sebesar nol (dua pangkat nol) dua ekor, sebesar 4 (dua pangkat dua) sebanyak dua ekor, titer sebesar 8 (dua pangkat empat) dua ekor dan titer 32 (dua pangkat lima) sebanyak empat ekor.Bedah bangkai pada hari ke 21 menunjukan patologi anatomi pendarahan ptechiae di pharynx dan trachea, dugaan kami ayam sudah terserang ND tipe pernafasan. Kasus ini terjadi di banyak tempat, diduga adanya rendahnya kekebalan pada induk ayam di breeding farm. Hal ini sesuai dengan Sufiriyanto, dkk,((2010)) yang mengatakan bahwa kekebalan terjadi diperlukan tingkat titer HI sebesar 8- 16 dan anak ayam niaga pedaging mulai menunjukkan sakit umur 12 hari, peneliti duga adanya kemungkinan rendahnya maternal antibody atau kekebalan bawaan dari induk tidak ada atau ada tetapi lemah, Sedangkan untuk meningkatkan kekebalan ND dapat diberikan herbal mengkudu dan temulawak (Sufiriyanto dkk, 2002), atau diberikan ekstrak mengkudu dan probiotik juga dapat meningkatkan titer HI untuk penyakit ND pada ayam niaga pedaging (Sufiriyanto dan Indradji, 2005) Kondisi ayam niaga pedaging semakin menjurus ke sakit ND dengan gejala tortikolis (kepala putar2), diduga vaksinasi DOC kemungkinan ada kegagalan. Hal ini sesuai dengan Kencana, dkk (2012) mengatakan bahwa vaksinasi ND yang berhasil membentuk antibody adalah ayam yang 10 hari setelah di vaksin menunjukakn sehat pertumbuhannya optimal, nafsu makan meningkat, bobot badan meningkat dan performannya menjadi baik. Hal kegagalan vaksinasi umur satu hari dikarenakan rendahnya maternal antibody diperkuat Sianita, dkk (2011) yang mengatakan bahwa kekebalan vaksinasi ND live terbentuk optimal hari ke 9-14 setelah vaksinasi, 
Prosiding Seminar Nasional Pembangunan dan Pendidikan Vokasi Pertanian

Politeknik Pembangunan Pertanian Manokwari, 14 November 2020

e ISSN : 2774-1982

vaksinasi ND aktiv atau ND live dilaksanakan aplikasi tetes mata akan membentuk kekebalan antibody bersifat lokal dan kemampuan antibody local untuk menanggulangi terjadinya infeksi

\section{KESIMPULAN DAN SARAN}

Uji F secara simultan yakni faktor-faktor kinerja berpengaruh sebesar 98,7 persen terhadap indeks produksi ayam broiler. uji t secara parsial yakni pertambahan bobot badan harian sebesar 20,2 persen, daya hidup sebesar 30,1 persen, dan konversi pakan sebesar 48,4 persen terhadap indeks produksi ayam broiler. Konversi pakan merupakan faktor yang paling dominan berpengaruh terhadap indeks produksi, diikuti oleh daya hidup, dan pertambahan bobot badan harian.

\section{DAFTAR PUSTAKA}

Dahlan, M. (2011). Studi Manajemen Perkandangan Ayam Broiler di Dusun Wangket Desa Kaliwates Kecamatan Kembangbahu Kabupaten Lamongan. Jurnal Ternak. 2(1): 24-29.

Herlina, B., R. Novita, \& T. Karyono. (2015). Pengaruh Jenis dan Waktu Pemberian Ransum Terhadap Performans Pertumbuhan dan Produksi Ayam Broiler. Jurnal Sain Peternakan Indonesia, 10(2); 107- 113.

Kencana, G.A.Y., N.M. Astawa, I.G.N.K. Mahardika, \& II.W. Gorda. (2012). Penyebaran Virus Vaksin ND pada Sekelompok Ayam Pedaging yang Tidak di Vaksinasi dan Dipelihara Bersama Ayam yang divaksinasi. Buletin Veteriner Udayana, ISSN: 20852495. Vol. 4 No. 2: 109-117.

Pratama, A., A. Rusdinar, \& Setiadi,. (2015). Perancangan dan Realisasi Protype Sistem Kontrol Otomatis untuk Kandang Anak Ayam Menggunakan Metode Logika Fuzzy (Pemberi Pakan, Conveyor Berjalan, Kendali Suhu dan Kelembaban ). Prodi S1 Teknik Elektro. Fakultas Teknik. Universitas Telkom. Bandung.

Prihandanu,A., A.Trisanto, \& Y.,Yuniati. (2015). Model kandang Closed House Otomatis Menggunakan Omron Sysmac CPM 1 A 20-CDR=A. VI. Jurnal Rekayasa Dan Teknologi Elektro 9(1): 54=62 .

Sianita, N., Z. Hasan, \& R. Kusriningrum. (2011).Respon Antibodi dan Produktivitas Pada Ayam Pasca Vaksinasi Menggunakan Vaksin ND Aktif Lv 12.. Jurnal Veterinaria Medica. 4(2): 129=134.

Sufiriyanto, Indradji, M \& P ayitno. (2002). Pengguanan Ekstraks Rimpang temulawak dan Buah Mengkudu untuk Meningkatkan Kualitas Kolesterol dan Trigliserida Darah Ayam Pedaging. Media Kedokteran hewan.UNAIR. Surabaya.

Sufiriyanto \& Indradji M. (2005). Efektivitas Pemberian Mengkudu dan Probiotik terhadap Produktivitas dan Titer Kekebalan ND pada Ayam Niaga Pedaging.

Sufiriyanto, M. Indradji \& I, Supriyanto. (2010).The Effectivenes of Morinda Citrifolia, Curcuma xanthoriza and Curcuma domestica Extract For Immunostimulatory Titer Antibody New Castle Disease and Avian Influenza on broiler.Procedings International Seminar. The $1^{\text {st }}$ Internatonal Seminar and the $7^{\text {th }}$ Biennial Meeting 
of Indonesia Nutrition and Feed Science Association. Emppwerment of Local Feeds to Support Feed Security.

Sufiriyanto, Ning Iriyanti \& Emmy Susanti. (2018). Hematology Profiles and Performance of Broiler Chickens Feed on Commercial Feed. Annimal Production. Scientific Journal of Farm Animals and Feed Resources in the Tropic.Faculty of Animal Science Jenderal Soedirman University in collaboration with Indonesian Society of Animal Science. Volume 20. Number 3, 2018.

Wijayanti, P., W. Busono \& R. Indrati. (2013). Effect of House Temperature On Performance of Broiler in Starter Period. Jurnal Peternakan. Fakultas Peternakan. Universitas Brawijaya. 